\title{
A Qualitative Study of Undergraduate STEM Majors' Copyright Knowledge and Educational Experiences
}

\section{Sara Rachel Benson, Kelli Trei, and Merinda Kaye Hensley}

\begin{abstract}
This study sought to better understand students' grasp of complex copyright issues. Thirty-one undergraduate STEM students were interviewed to learn more regarding what students know about basic copyright and how they learned what they know about it. The interviews revealed that students often conflate aspects of copyright and plagiarism. Most students also indicated a desire to receive formal instruction regarding copyright. The use of case studies as the foundation of the interview process demonstrated that copyright instructional efforts can be designed to meet students where they are throughout their disciplinary educational experience, while also connecting to their personal life experiences.
\end{abstract}

\section{Introduction}

The focus of this study is to investigate how undergraduate students studying science, technology, engineering, and math (STEM) comprehend the complexities of copyright and how they learned what they know. To date, there is little understanding in the literature regarding undergraduates and copyright, making this qualitative study a first attempt at exploring their understanding so that librarians can build on students' real-world experiences.

This research was inspired by a particular finding from the results of the 2018 Ithaka S+R University of Illinois at Urbana-Champaign Undergraduate Student Survey. ${ }^{1}$ A sample of 30 percent $(9,775)$ of the degree-seeking undergraduate students ( $>18$ years old) enrolled at the University of Illinois were invited to participate. Of these students, 974 respondents completed the survey in its entirety, which resulted in an overall survey response rate of 10 percent. One survey question asked, "How important or unimportant is it to you to acquire each of the following research skills as a result of your experience at this college or university?" In response, one of the options was to rank the concept of "using information ethically (i.e. understanding the concept of intellectual property, copyright issues, and/or other legal and ethical standards for the conduct of academic research)" on a Likert seven-point scale ranging from "very important" to "very unimportant." A total of 930 students answered this question, with 33.76 percent

\footnotetext{
* Sara Rachel Benson is Assistant Professor, Copyright Librarian, and Interim Head of the Scholarly Commons; Kelli Trei is Associate Professor and Biosciences Librarian; and Merinda Kaye Hensley is Associate Professor and Digital Scholarship Liaison and Instruction Librarian, all at the University of Illinois Library; email: srbenson@ illinois.edu, ktrei2@illinois.edu, mhensle1@illinois.edu. (02021 Sara Rachel Benson, Kelli Trei, and Merinda Kaye Hensley, Attribution 4.0 International (https://creativecommons.org/licenses/by/4.0/) CC BY 4.0.
} 
responding that it was "very important" to use information ethically, 34.52 percent indicating that it was "important," 15.91 percent stating that it was "somewhat important," only 5.37 percent of respondents asserting that it was unimportant, and 10.43 percent answering that it was "neither important nor unimportant." The fact that many undergraduates found the ethical use of information, including copyright issues, to be an important research skill was surprising, given the hypothesis that copyright literacy is rarely taught to undergraduate students within the context of their courses. However, the survey design combined copyright and using information ethically in the same question, which in the minds of students could include the concept of plagiarism, making it difficult to surmise whether students value copyright knowledge or plagiarism instruction independent of each other. Due to the prevalence of the discussion of plagiarism in student codes of conduct on university campuses, this seems to be the more likely valuation. All undergraduate students, whether they recognize it or not, create copyrightable material.

For the sake of this study, the authors decided to focus on a subset of students with shared experiences. Students in STEM studies create a widely varied selection of materials such as papers, laboratory notebooks, photographs, and computer code; they were therefore compelling as a group. Thus, the researchers sought to understand students' comprehension regarding copyright as it applies to their student-created work and whether they receive instruction regarding copyright in their undergraduate STEM educational experience.

\section{Literature Review}

As noted by Nancy Sims, while limited empirical research is available on the subject of undergraduates' knowledge of copyright, the research that has been conducted indicates "students' knowledge of copyright is generally lacking." 2 In fact, most studies on copyright understanding and undergraduate students are international. For example, in a 2017 survey across multiple institutions in Nigeria, researchers sought to discover how much students know about copyright infringement. ${ }^{3}$ The survey results indicate that the majority of students were aware of copyright laws and that they infringed on copyright in a variety of ways including reproducing and distributing works from the internet without the author's permission. ${ }^{4}$ However, the same study indicates most students surveyed agree that copyright infringement is "a form of intellectual dishonesty." ${ }^{5}$ In another study conducted in 2015, Spanish undergraduate students "almost overwhelmingly answered incorrectly to questions assessing knowledge of basic copyright concepts in their national laws." 6 Taiwanese students demonstrated similar confusion in a 2007 survey. ${ }^{7}$ Graduate students in the United Kingdom answered similar questions slightly more accurately. ${ }^{8}$ Sims noted that, at the time of her publication, she was "unable to locate quantitative research specifically on the copyright knowledge of students in the United States, whether graduate or undergraduate." 9

The amount of quantitative data regarding undergraduate students' copyright knowledge is slight, and the number of qualitative studies of undergraduates' copyright knowledge is limited to a small portion of a single study. In a mixed methods study of undergraduate students' knowledge of scholarly communication across two different institutions (Purdue University and University of Illinois at Urbana-Champaign), researchers found that "[i]nterviewees could not accurately address copyright and author's rights as applied to their scholarship." 10 In the context of 17 student interviews, the researchers concluded that students from a variety of disciplines were unclear about who owns the copyright to their student-authored works and 
stated they "received little or no guidance related to their rights as authors and other legal implications of sharing their research."11

While students may rarely be taught about the complexities of copyright in their courses, information literacy and scholarly communication librarians are increasingly developing educational initiatives that align copyright to an undergraduate perspective. This type of instructional change is largely due in response to the shift toward student-authored work through such high-impact educational practices as undergraduate research and capstone projects including humanities and social science disciplinary efforts to pair faculty with students (such as the "Students as Partners" initiatives supporting teaching and learning). ${ }^{12}$ There are also a growing number of students submitting their undergraduate theses to open institutional repositories, a situation that presents an opportunity to go beyond the novice expectations surrounding the ethical use of information to the more complex idea of what it means to put a license on their own work. The ACRL white paper, Intersections of Scholarly Communication and Information Literacy: Creating Strategic Collaborations for a Changing Academic Environment, called for educational initiatives to support undergraduates as they learn about scholarly communication issues as content creators. ${ }^{13}$ The paper states, "Whereas being able to apply copyright law to the most common ways of working with content in higher education was once a matter of applying a set of rules, it is now necessary to help our communities apply critical thinking skills in order to integrate a more fundamental understanding of our copyright regime." ${ }^{14}$ There are an increasing number of case studies in the literature that librarians can use as a jumping-off point for developing their own copyright lessons. Kevin L. Smith and Erin L. Ellis offer a framework for teaching copyright though a collection of eight in-depth case studies using a variety of instructional strategies including role-playing, storytelling, and "coaching up." ${ }^{15}$ Elizabeth Joan Kelly provides an in-depth review of the literature on copyright instruction for undergraduates including best practices of rights instruction along with several case studies of current teaching practices geared toward the specific learning needs of undergraduate students. ${ }^{16}$ Gail Clement and Stephanie Brenenson discuss an innovative approach by situating copyright instruction in popular culture or familiar media and asking students to "contemplate their roles, responsibilities, and choices as they create and disseminate projects and papers throughout the course of their academic careers." ${ }^{17}$ Molly Keener outlines case scenarios that highlight allegations of infringing activities as a way to reach undergraduates with topics that interest them. ${ }^{18}$ Perhaps most important, Kyra Folk-Farber points out that, once students begin to recognize their place in the academic community and the copyright implications of being a content creator, "It is also the moment that they begin to develop communities of informed practice, and those communities of practice will extend beyond graduation, no matter what career paths those students take."19

The acknowledgment that copyright as a concept is an instructional responsibility of librarians is well-documented throughout our professional standards, although there are identified roadblocks to its development. The major professional library organizations mention copyright in their core competencies. For example, the American Library Association includes copyright as part of the legal foundations of the profession. ${ }^{20}$ The Special Library Association includes understanding the ethical implications of copyright in their core competency of Information Ethics. ${ }^{21}$ The ACRL Framework for Information Literacy for Higher Education mentions the copyright component in the "Information Has Value" frame, stating, "As creators and users of information, experts understand their rights and responsibilities when 
participating in a community of scholarship." ${ }^{22}$ While these competencies are clearly stated, and evidence exists that librarians seek to incorporate discussion of copyright in their instruction initiatives, there also remains a lack of copyright education for librarians themselves that may be the underlying reason for hesitancy to teach copyright. In 2015, researchers reported that 62 percent of survey respondents who received copyright instruction in library school found it to be less than needed in practice. ${ }^{23} \mathrm{~A}$ subsequent survey of LIS students indicated that, although the majority were familiar with copyright basics, many lack understanding of copyright exceptions and more than 40 percent were unfamiliar with issues related to works in the public domain and digitized materials. ${ }^{24}$ Conversely, more than 90 percent of the LIS students surveyed felt they should receive copyright training as part of their graduate education, demonstrating new librarians see the value in learning about and teaching copyright, even if they do not have the skills coming into the profession to do so effectively. ${ }^{25}$

\section{Research Questions}

This study was designed to begin to address significant gaps in the literature regarding undergraduate students' knowledge of copyright concepts and to gauge their understanding of educational training experiences regarding copyright. For this study, the researchers chose to sample undergraduate students from a variety of STEM fields. The following research questions informed the research design:

- What do undergraduate students in STEM know about basic copyright requirements and rights?

- How did undergraduate students in STEM learn what they know about copyright?

- From student reporting, have undergraduate STEM students received any formal educational instruction about copyright?

\section{Methodology}

The research method chosen for this study as a qualitative interview approach was used to identify themes revealed in the data while allowing students to freely explain their understanding of the issues presented in two case study examples. ${ }^{26}$ The University of Illinois at Urbana-Champaign Office for the Protection of Research Subjects reviewed the research application and determined the study exempt. The semistructured interviews took place during October-November 2019. The researchers applied for, and were awarded, funding from the University Library's Research and Publication Committee to be used to hire an external company to perform the transcription of interviews and for gift cards as incentive for participants.

Undergraduate students enrolled at the University of Illinois at Urbana-Champaign majoring in a STEM field (as defined by the Department of Homeland Security) were invited to participate in a 20-minute interview session. Homeland Security classifies a STEM discipline as any field that is included in the Department of Education's Classification of Instructional Program taxonomy as biological and physical sciences, mathematics, or related fields. ${ }^{27}$ The purposive sampling of STEM fields was selected for this research as students studying in STEM fields tend to have hands-on practice with a variety of copyrighted materials during their time as undergraduates ranging from scholarly literature and journal articles, to images, to software code. Similarly, students may have experience creating copyrightable materials such as lab notebooks, coding software, and photographs of biological specimens. 
Students were recruited by placing physical and digital flyers in the Undergraduate Library, the Funk Agricultural, Consumer and Environmental Sciences (ACES) Library, and the Grainger Engineering Library Information Center. One of the researchers encouraged library student workers and their peers to participate in the study, which resulted in several word-of-mouth participants. Calls for participation were also included in the library's social media platforms. Recruitment language included a link to an online form that collected the student's contact information, which was used to schedule the interviews. Forty-one students completed the form expressing interest in participation in the study, and 31 students scheduled interviews. The authors acknowledge that the survey sample is not representative of all STEM areas equally. At the start of the interview process, participants were briefed on the purpose of the interview and asked to sign a consent form that explained the purpose of the study, the reasons for recording the session, and how the data would be used. Students were also asked to confirm they were at least 18 years of age. Participants were provided with a paper copy of the consent form for their own records. By participating in this research study, participants agreed to an audio recording of the session for transcription purposes. Participants could choose to leave the interview at any time and still be given the incentive for participating. Recordings and transcriptions were kept in an institutional cloud folder only accessible to the three researchers, and the audio was destroyed once the transcriptions were complete. Students were informed that personal identifiers would not be published or presented, and de-identified information may be used for future research without additional informed consent. Each participant received a \$25 Amazon gift card via email shortly after the conclusion of the interview process.

Interview protocol was the same for each student, with two interviewers in the room for each interview; however, in one interview, due to scheduling conflicts, there was only one team member present. At the beginning of the interview process, participants were given the first case study with time to read and review. (For full text, see Case Study Nos. 1 and 2.) The students were encouraged to take notes during the interview process, which students were informed would be kept anonymous and only reviewed for research purposes; however, no one took advantage of this suggestion. Once the participant finished considering the first case study, the interviewers asked three structured questions. As the conversation unfolded, the interviewers contemporaneously asked follow-up questions. Because of this, each interview took a unique direction based on the interests of the interviewees and the researchers. Once the participant and interviewers felt the conversation regarding the first case study came to an end, the participants were given time to consider the second case study. This scenario included six prepared questions. The case studies were designed to build on each other to gauge the participant's understanding of basic copyright principles as applied in an educational setting. The researchers used an audio recorder to tape the conversation and also took notes throughout the interview process. Upon conclusion of the interview process, participants were provided with a handout that included explanations of the copyright implications for each case study (see appendix: Handout for Conclusion of the Interview).

The audio recordings were sent to an external company for transcription, given that it is a time-intensive and detail-oriented process. ${ }^{28}$ Once the interviews were transcribed, two of the researchers worked as a team and one worked individually to review the data, using open code methods to code the interview transcripts and analytical coding to identify related themes. ${ }^{29}$ Two of the researchers also used Atlas.ti software to code the transcripts while one researcher preferred to code "by hand," printing out the interviews and using colored pens 
to highlight themes and quotes of particular interest. After the dual coding process of the qualitative data was complete, connections and anomalies were explored among the team of three researchers.

\section{Case Study No. 1 (CS1)}

You are taking a class about nature and the environment. One of your assignments for class is to take a photograph in a natural environment, write a short paragraph about the photograph, and submit it for a grade in the class. You go to a local park over the weekend and take a photograph of a butterfly landing on a local flower. You write a paragraph about why you chose that particular scene for the assignment, noting that the flower is a local variety and, as such, highlights the local environment.

Give some thought to the ownership of the photograph-who owns it? Please outline your thought process about the ownership of the photograph.

The following three questions were used to begin the conversation with additional questions as needed:

1. What do you mean by ownership?

2. Who owns the copyright of the photo?

3. What do you need to do to have a copyright of the photo?

\section{Case Study No. 2 (CS2)}

You are taking the same class about nature and the environment. Later in the semester, the professor asks you to create a poster to show to the class about a particular subject in the natural world. You choose to create a poster about polar bears. Because you do not have any photographs of polar bears that you have taken yourself, you look on a professional photographer's website and download a copy of a photograph taken by a professional photographer. You incorporate the photograph into your poster. In the credits section of the poster, you include a citation to the photographer's name, the title of the photograph, and the location of the website where you obtained the photo.

Give some thought to the legal use of the photograph. Was your use of the photograph permissible under copyright law? Please outline your thought process about the legal use of the photograph.

The following six questions were used to begin the conversation with additional questions as needed:

1. Who owns the photo in this scenario?

2. Who owns the copyright of the photo?

3. Can you compare and contrast the two case studies?

4. Have you ever been in a formal classroom where the instructor discussed copyright? Is it in the context of your major? If so, which class?

5. Where else have you learned about copyright?

6. Do you think it would be useful to learn about copyright in your college courses?

\section{Demographics}

A total of 31 students participated in the interviews, each lasting approximately 20-30 minutes. Sixteen female undergraduate and 15 male undergraduate STEM students were interviewed. The interview participants included 12 freshmen, five sophomores, seven juniors, and seven 
seniors. The students' majors spanned disciplines in the life sciences and agriculture, engineering, physical sciences and mathematics, and the medical sciences. The two most prominent majors were computer science (10) and biology (7), with six students minoring in chemistry (see table 1).

\begin{tabular}{|c|c|c|c|}
\hline \multicolumn{4}{|c|}{$\begin{array}{c}\text { TABLE } 1 \\
\text { List of Students' Year in School, Majors and Minors }\end{array}$} \\
\hline Interview & Major & Minor & Year \\
\hline 1 & Biochemistry & Food Science/Chemistry & Junior \\
\hline 2 & Computer Science & $\mathrm{n} / \mathrm{a}$ & Freshman \\
\hline 3 & Astronomy & $n / a$ & Freshman \\
\hline 4 & Material Science and Engineering & Chemistry & Junior \\
\hline 5 & Biology & $\mathrm{n} / \mathrm{a}$ & Freshman \\
\hline 6 & Biology & Chemistry & Junior \\
\hline 7 & Biology & $\mathrm{n} / \mathrm{a}$ & Freshman \\
\hline 8 & Mathematics and Computer Science & $n / a$ & Senior \\
\hline 9 & Agriculture and Biological Engineering & Chemistry & Senior \\
\hline 10 & Applied Mathematics & Statistics & Senior \\
\hline 11 & Mathematics and Computer Science & $n / a$ & Sophomore \\
\hline 12 & Material Science and Engineering & $n / a$ & Sophomore \\
\hline 13 & Biology & $\mathrm{n} / \mathrm{a}$ & Junior \\
\hline 14 & Computer Science & Economics & Senior \\
\hline 15 & Civil Engineering & $\mathrm{n} / \mathrm{a}$ & Senior \\
\hline 16 & Engineering Physics & $n / a$ & Freshman \\
\hline 17 & Biology & $\mathrm{n} / \mathrm{a}$ & Freshman \\
\hline 18 & Food Science & Chemistry & Senior \\
\hline 19 & Computer Science & $\mathrm{n} / \mathrm{a}$ & Junior \\
\hline 20 & Specialized Chemistry & $\mathrm{n} / \mathrm{a}$ & Junior \\
\hline 21 & Mechanical Engineering & Communications & Freshman \\
\hline 22 & Bioengineering & Spanish & Sophomore \\
\hline 23 & Computer Science & Art and Design & Freshman \\
\hline 24 & Biology & Spanish & Sophomore \\
\hline 25 & Biology & Chemistry & Junior \\
\hline 26 & Computer Science & $\mathrm{n} / \mathrm{a}$ & Freshman \\
\hline 27 & Computer Science & $n / a$ & Freshman \\
\hline 28 & Computer Science & $n / a$ & Freshman \\
\hline 29 & Computer Science & Statistics & Freshman \\
\hline 30 & Chemistry and Political Science & $\mathrm{n} / \mathrm{a}$ & Sophomore \\
\hline 31 & Computer Engineering & $\mathrm{n} / \mathrm{a}$ & Senior \\
\hline
\end{tabular}

\section{Identified Themes and Discussion}

The interview coding process identified six general themes from the 31 interview conversations. 


\section{Theme 1: Students understand ownership, but are confused about copyright}

When presented with the case studies, most students were readily able to ascertain the appropriate owners of the photographs: the student as owner in Case Study no. 1 (CS1) and the professional photographer as owner in Case Study No. 2 (CS2). However, when asked who owns the copyright for the photographs, most students became confused and were uncertain about the specifications necessary to create a copyrighted work, referencing concepts like a mistaken requirement for copyright registration with the Copyright Office or some other federal agency. For instance, when asked who owned the copyright in CS1, which involved the student taking a photograph in a park, one student replied, "I don't know exactly... there's a process I'm sure. And you have to file it with some, maybe, copyright office." (senior, computer science/economics) Most students responded in a similar fashion. Only two students understood that modern U.S. copyright law requires no formalities to have a valid copyright, such as providing a copyright symbol on the work or renewing the work with the copyright office. One student correctly noted, when discussing CS2 and the relationship between copyright and the internet, "Copyright is automatically granted to the person who takes the photograph. I read this somewhere... one of the things I clearly remember is even if your work is available on the internet, [and] there's no prior license, there's automatically a copyright on it... and you still retain all the rights unless you disclose that you want to release it in some form." (freshman, computer science/statistics)

Interestingly, the same students who believed that formalities were still required seemed to assume the professional photographer had gone through the steps necessary to own the copyright for the photo in CS2. They seemed to infer that, if a photographer was a "professional photographer" as the text implied in CS2, then they would go through the necessary steps to protect the copyright, whereas the student submitting the work for a class project would not.

The students were asked in a structured question to explain what they meant by the term "ownership." Although the students were confused when they were asked about copyright specifically, many seemed to understand the exclusive rights of copyright intuitively because many of their definitions of ownership related to the Section 106 exclusive rights of copyright authors. ${ }^{30}$ For example, four students described ownership in terms of creativity, such as "the primary creator... you originally have those ideas and you're the one that actually brings those into fruition..." (junior, materials science and engineering/chemistry) This demonstrates understanding of the constitutional requirement of originality, which courts have further defined as the minimal level of creativity required for a copyright to exist. ${ }^{31}$ Five students mentioned in various manners the specific rights of the author to distribute, reproduce, and create derivatives of the work, which are all encompassed in the Section 106 list of rights that are exclusive to the author of a copyright in the Copyright Act. ${ }^{32}$ To illustrate, one student noted that ownership means, "If I want to alter the photo, if I want to keep the photo and not give it to anyone else, it's my right to do that without involving anyone else in the whole equation." (freshman, engineering physics)

A few students mentioned outdated (at least for copyright law) meanings of ownership referring to the effort put into taking the photo or the long-overruled sweat-of-the-brow theory of copyright ownership. ${ }^{33}$ Five students referred to physical ownership, including the ability to sell or market the physical work, which is more consistent with the legal concept of ownership of physical property as distinguished from intellectual property or copyright ownership. Five students also referred to the requirement that others attribute the author as 
the one who took the photo, which seems to relate more to their understanding of plagiarism rather than copyright, although some judges have found it important to demonstrate good faith in fair use determinations. ${ }^{34}$ Alternatively, this may also be an overzealous transfer of knowledge from having seen various Creative Commons licenses on open educational resources.

Students also spent a significant amount of time considering the fact the park was described as a "public park" in CS1. Nearly half of respondents mentioned the importance of the park as a public space or a place where photography was not a controlled, private location.

I believe that's because if it's at a local park, I'm assuming that the local park itself is free to open to take pictures. And since it's a public area that means it's for public use... So, technically it doesn't have anything to do with copyright, I guess it has to do with legal issues. If it was private property and it was governmentally owned and regulated, and you weren't supposed to go inside, then yeah, I would assume you'd get in trouble for that. Yeah, that's mainly it. (junior, biology/chemistry)

\section{Theme 2: Students frequently confuse copyright with plagiarism}

Students tend to conflate plagiarism principles with copyright rules and tend to think they involve the same concept. This is likely grounded in the abundance of plagiarism instruction students received at both high school and college levels, in comparison with the dearth of copyright instruction provided to students in either scholastic setting. When asked about whether they had ever received formal (scholastic) training in copyright, almost all of the students said "no." On the other hand, many participants mentioned they had received some kind of training in plagiarism at the high school level, college level, or both.

Participants seem to conclude the scenario in CS2 is representative of legal use in large part because the student in case study 2 included a citation to the photographer and the website from which the photograph was taken. One student said, when comparing the two case studies to each other, "This time you are giving them credit. So, I want to say it's allowed actually. To me, if someone else did that, I would say that sounds about right." (junior, biology/ chemistry) Similarly, another student noted, "they gave credit where it was due, especially since it was just a digital copy, I think it would be fine." (senior, agriculture and biological engineering/chemistry)

Of course, proper citation is crucial to academic attribution, maintaining the scholarly record, and avoiding charges of plagiarism, so it makes sense that students focus on this fundamental issue provided in the case study. It is imperative for students in an academic setting to learn about plagiarism, as they might otherwise run afoul of academic norms and be subject to lowered grades, student conduct discipline, and more. However, the question posed to the participants at the end of CS2 was whether the student's use of the photograph in class poster was legal, not whether it constituted plagiarism. The face-to-face teaching exception to copyright does not require citation for the work to be legally displayed or performed in class. Similarly, while some judges do consider citation to be a factor in favor of a good-faith application of fair use, the statute does not consider citation to be one of the main principles of fair use. ${ }^{35}$ Many authors have successfully defended a fair use claim without ever having cited the author of the underlying work on which their work is based. 


\section{Theme 3: Students understand the meaningful difference between commercial and educational use}

Students often noted the freedom to use a copyrighted image without seeking permission, especially in CS2, where the student did not take the image herself but borrowed the image from a professional photographer, was more permissible in the context of nonprofit educational use. A majority of the students mentioned that, if they wished to sell the poster containing the professional photograph, the legal analysis would likely change. For instance, when discussing the use of the professional photo in CS2, one student said, "I feel like, for educational purposes, it would be okay... If you're selling something, or putting it on your product, I feel like that wouldn't be acceptable because usually, if it's used for your own personal gain, like to make money or something, there's usually legal issues." (sophomore, bioengineering/ Spanish) Another student agreed by stating, "for photos,... usually you should give credit to the photographer and as for copyright... if you're making money off of it, you shouldn't." (freshman, computer science) When asked whether they would need to first ask permission to use the photo for an educational use, that same student replied, "I think usually no." A third student made the comparison even more clear when stating, "This is a school project, so I know there's something with some law, I forget the name, where if you're using it for educational purposes, it's okay. But I'm sure if you made a picture book and sold the book, it'd be different." (senior, computer engineering).

A few legal principles intersect to create this distinction between classroom use versus commercial use. The first is a copyright exception contained in Section 110(1) of the Copyright Act allowing the display or performance of any work (including full-length movies) by teachers or pupils in the course of face-to-face teaching. The second is the factors of fair use, which consider, in part, whether the purpose of the use was for a commercial or nonprofit, educational purpose. Whether or not the students understood the legalities behind the use of the photo, they did seem to understand there was a distinction between nonprofit and profit usage.

\section{Theme 4: Students engaged in copyright-related activities that intersect with their hobbies retain accurate copyright information}

Very few students indicated they had received any formal educational training on copyright. However, at least 11 students held an accurate understanding of copyright rules. What was perhaps the most fascinating part of this study was learning where, exactly, the students with comprehensive copyright understanding gained their knowledge.

Eight of the students mentioned they informally acquired copyright information from YouTube. Students mentioned YouTube when discussing topics like copyright infringement, fair use, and the improper use of copyrighted work without permission. Due to their knowledge of issues surrounding YouTube creators' rights, students are attuned to broader discussions about copyright policy such as legal arguments calling for the reform of the Digital Millennium Copyright Act (DMCA), without fully understanding the underlying law or the technical names for the legal arguments. ${ }^{36}$ Perhaps this should come as no surprise, as copyright librarian Nancy Sims notes that in her experience students, both graduate and undergraduate, "rapidly grasp the complexities of the signals about legitimate and illegitimate use for YouTube users." ${ }^{37}$

Students also mentioned YouTube when discussing fair use. For instance, one student noted that using the photograph for educational purposes in CS2 could be a fair use. When 
asked how they had learned about fair use, the student responded, "I play video games a decent amount. I've seen YouTube videos where people play those games in them. Obviously, everything in the games is the copyright of whatever company made the game, but because they're playing through it and creating their own work out of it, it's fair use for them to then make money off of the videos of them playing the game at least. I think that's fair use." (senior, mathematics and computer science) That same student was familiar with the concept of transformative fair use from videos of individuals playing video games as well,

"I had been watching a creator's videos and then a company tried to take them down. And I've seen a number of videos where they kind of talk about how they fought back against having it taken down. And in those videos, they're like, this is what the lawyer had said we were going to try to claim, it was transformative and because it was different enough from the original work or created by them somehow then they had the right to do what they wanted with it."

What is striking is not only the depth of knowledge the student retained about fair use, and transformative fair use in particular, but the context in which the student learned about fair use. This particular student learned about fair use in connection with a topic of interest: in this case, video gamers recording and posting video games of themselves playing games on YouTube.

Another student learned about copyright in connection with playing an instrument in a band. The student noted:

"I've played in bands my entire life, with instruments. And a lot of times when you have purchased music, the original composers, you buy it in a set. It's very expensive... And it'll come with a certain number of parts... But the problem is not every band has the same number of people. So, if you have six flutes and there's only four pieces of music, you might take those... originals and... put them through a photocopy machine. And then you can have those [photocopies] just [for] classroom use." (junior, materials science and engineering/chemistry)

There were a few students who learned about copyright and retained the information from high school education, including a few students who learned about it from a combination of sources, including YouTube, involvement in band, their hobbies, discussions with family members, and internships.

\section{Theme 5: STEM fields provide distinctive copyright experiences to students} In most subject areas, students write papers and often prepare presentations in the form of posters for class. In STEM fields, in addition to these pursuits, data and output can take many additional forms. In computer science this might be coding; in laboratory science this may be information shared in lab notebooks such as images or drawings; in the field this could be photographs of nature or video footage of animals interacting. Students in these areas of study struggled in the interviews with the concept of whether they owned these kinds of creative outputs. 
The students who had experience with coding seemed to understand that they could potentially own a copyright in their own creative output. Although some students still struggled with whether a student, rather than a company, could own a copyright in code, other students had a fairly in-depth understanding for how copyright applies to coding. For instance, some students noted that writing "standard" code such as a method of operation is not creative enough to permit a copyright as demonstrated by the quotation below.

If I'm [writing code] just for school, like homework, then I'd say it's mine. But again, in that situation it doesn't really matter. The code is a lot like a group of 500 students are doing the code in their own way. So, in that situation, the copyright laws really don't matter, I'd say. I mean if someone did take my code and do something with it, I don't know, I wouldn't say anything because there's 500 people who've done the exact same thing. It was usually in our homework, at least the level I am at right now, the questions are very basic and usually everyone's going to give the same answer. So, in that situation, copyright can't really exist because there's a question and then there's the correct answer. So, you can't say that, oh, everyone is copying the same answer. So, it's the same question, answer format for any exam. An answer isn't copywritten, or anything, at least according to me. (freshman, engineering physics)

Students also expressed understanding the concept of "work for hire" where the company and not the employee owns the copyright for a work created within the scope of the employee's duties. As discussed under the previous theme, this advanced understanding might be partially attributed to the fact students often had internship experience coding for private companies. For instance, one student explained that if one works for a company and "...they write this piece of code... it's definitely not theirs, it's the company's." (freshman, computer science/statistics) Similarly, an engineering student, when discussing CS2, noted "the photographer did take [the photo,] but they may have taken it for a company or somebody else like National Geographic. So, although they took the photo, it... may be copyrighted under National Geographic." (senior, civil engineering) Another computer science major agreed, responding to the question of who owned the photo in CS2, "I think it's a photographer because they took it or if they're managed by a brand or like a company, the copyright would belong to them." (freshman, computer science) Most students also expressed an understanding that using code belonging to private corporations would be illegal without permission, "I guess if you're looking at code that belongs to an organization or a company, I guess that's out of bounds. You can't use that code." (sophomore, mathematics and computer science)

The confusion over copyright seemed to manifest itself more in regard to other output such as work created in a laboratory project or papers. This became particularly confusing for students who had done some of this type of work for credit or while employed. There were quite a few comments that highlighted different types of intellectual property such as patentable versus copyrightable, demonstrating how this type of output can present a variety of complexities. Work done in a laboratory for which a student is getting credit often has no intellectual property ramifications. However, if a student is hired into a research lab, the lab may have other agreements in place related to intellectual property that make the laboratory notebooks property of the lab, or university. To complicate things further, from an intellectual 
property perspective, if the student has contributed unique processes to the research, they also might want to know how they maintain intellectual property over their unique contributions within this larger framework.

One student seemed to have a basic understanding of this distinction. When asked who has ownership of their lab notebooks in a position for which they were paid, "My Principal Investigator. So, she's the person that's in charge of the project and the research... I'm just a lab rat." When the student was asked to clarify that work versus what they were doing for a specific course, they replied, "You. You own the lab report, but you do have to give credit to the references that you did get the main, basic foundation from." (junior, biology/chemistry)

More confusion occurred when students were contemplating the idea of "scooping" or the worry a competing lab might publish something first or "steal" information before a paper was ready,

"We had this weekly meeting and then towards the end of publishing something. I was co-author on a paper and towards the end of publishing it... 'Don't tell anyone that we're doing this. Wait for two months-ish, and then you can tell whoever you want and put it on your LinkedIn and be happy about it. But just for this much time, don't tell anyone that we're doing this.' Yeah, that's when I put that and also, I think there's a discussion of me going to a conference and she wants me to have it published before then so that nobody at that conference steals my ideas. So, that's where all this came in." (senior, food science/chemistry)

Beyond this initial confusion is the broader concern that this student was unaware of their rights as an author when co-publishing a paper. When asked what the nature of the copyright agreement was on a co-published paper, they said, "Actually, I don't think I signed anything. My name was just on there and then I was notified by the journal that my name's on there and that's it."

From these conversations, it was clear that in many areas of STEM the lines of copyright, intellectual property, work for hire, and creative endeavors become very blurry for undergraduate students and is an area ripe for copyright instruction. Arguably, it may be even more important for undergraduate students to learn about copyright because much of STEM work is never conventionally published; rather, it is more likely to be patented.

\section{Theme 6: Students are receptive to undergraduate copyright education}

The vast majority of students (24) said they had not had any formal course discussion of copyright. It is very interesting, however, that many of the participants thought formal copyright instruction would be valuable. When students were asked whether they thought copyright should be taught, only three thought it would not be useful. One of those students dismissed the notion this way: “That's a hard question. I don't believe it affects everyone's lives at this point, whenever we're still young. But maybe in the future if we want to have our own creative ideas and writing, especially if you want to be published on our own, then we have to know about copyright laws. Or if we plan on starting a business as well. But I mean, like myself, not really. I don't need to know much about it." (junior, biology/chemistry)

While a few students expressed reticence regarding copyright instruction, the vast majority felt it would be a positive endeavor, with 16 students stating it "would be useful" and 
three stating "maybe it would be useful." One respondent highlighted this education as a tool to understand their author rights: "I know there are going to be more research papers and if I want to publish my own paper then I would definitely need to know about who actually owns my work and how to go about using other people's work in my papers and how to accredit that." (sophomore, biology/Spanish)

Several students were adamant about the importance of copyright education:

"Yeah, I think it's actually critical to know about this. I think in college many people create a lot of things, they write essays, make presentations. Copyright is like a pretty fundamental part of the law. Like all of the entertainment that we consume it's protected under copyright. So, it's normally not something we think about, but in the situation that we were ever to create content or even use other people's content, it's, like, critical to know these rights that protect the content creators." (freshman, computer science)

The researchers also asked students if they would value copyright instruction in addition to their learning experiences around plagiarism. One student replied positively, "Yes, because I don't exactly know what it is. There's like plagiarism and stuff and like I said patents but like I don't, I think patents are on products, but I don't think you can get copyright on products. It's like copyright is if you have an idea or something like that. I think, I'm not sure." (freshman, computer science)

\section{Informal, Secondary Conversation}

As the interviews migrated into less formal conversation and the tape recorder was turned off, the researchers intentionally let the discussion continue to evolve with the participants. The copyright librarian in particular used this opportunity to build on the case studies while crafting alternative, relatable examples that might resonate with each students' interests to further explore where their conclusions of the case studies may have been on target and where their assumptions may have gone wrong. The researchers encouraged participants to ask further questions regarding the two case scenarios as a review of the interview process. Some students choose to ask clarifying questions and others specifically mentioned how helpful the interview process was for them and that learning valuable takeaways about copyright could apply to their own work. Hence, the additional conversation provided students not only with a few moments of additional direct feedback, it doubled as an educational opportunity.

The research planning process did not prepare the researchers for how instructive this part of the interview process would prove to be; some of the more enlightening comments came from students during the informal conversation. One student, likely understanding the complications of their choices, asked for advice regarding the legality of torrenting books for their courses. Others reflected on their answers and asked for clarification using examples they have faced in their undergraduate scholarly work. Several students elaborated on their goals for the future and how copyright might impact their work. For example, one student mentioned they would like to publish in the future and would need a better understanding for who owns their work, detailing a situation where they could not remember if they had signed a publication agreement when submitting a paper with a supervising graduate student. Students also provided insight into how they view using others' work and how that impacts their 
thinking for generating their own scholarship and creative products. One student connected their current coursework to how they philosophically approach their discipline, in this case coding, as one that is open to sharing and constantly improving and building upon others' previous work. This student recognized collaboration as an essential component positioning recognition in a more complex way than simple attribution. And finally, although the majority of students interviewed remain confused regarding the legal requirements of copyright, they overwhelmingly indicated at the end of the interview the process had sparked an interest in better understanding copyright.

Once the informal conversation came to a natural conclusion, participants were thanked for their time and provided with a handout that included explanations for both case studies and online resources for more information. The handout also included a link to a LibGuide created by the copyright librarian that highlighted several elements of copyright law common to issues seen in higher education including misconceptions of copyright, a Q\&A section, and outlining "ground rules" related to copyright, such as "There is no special symbol (such as the copyright symbol) necessary on the protected work since 1989-it is protected simply because someone created it and wrote it down or recorded it" and "Ideas can't be copyrighted, only the tangible expression in a fixed medium of the idea can."

\section{Conclusion}

This study is the first stepping stone to better understanding students' grasp of complex copyright issues, including their author's rights as content creators. While several of the interview participants muddled their understanding of copyright with that of plagiarism in an academic environment, there is no reason to let confusion stand as most were primed for instruction related to copyright. It is important to note that STEM fields, in particular, create unique challenges when undergraduates are attempting to navigate the distinction between creative works and patentable works. However, these interviews revealed that undergraduate students engaged in hobbies or internships involving copyrightable materials develop a greater understanding of copyright issues overall. The use of case studies as a basis for the interview process seemed to positively resonate with the students, a notable pedagogical approach for relating to undergraduates that is also reflected in the current literature on copyright instruction models. It is also promising that most students who participated in this research think learning about copyright should be part of their education, and meeting students where they are is a compelling approach for teaching complex scholarly communication topics such as copyright.

There are myriad opportunities for research in this area. For example, under what instructional circumstances are students able to retain copyright information from their coursework and transfer that knowledge to their own creative works? We theorize it is also worth delving deeper into students' copyright knowledge on a continuum to better interpret the link between students' hobbies and how that understanding translates to making decisions related to copyright. Finally, as STEM fields have particular disciplinary habits of mind, there is substantive room to further investigate students' copyright understanding in alternative subject areas such as the social sciences and the humanities.

\section{Acknowledgments}

The authors wish to acknowledge the Research and Publication Committee of the University of Illinois at Urbana-Champaign Library, which provided support for the completion of this research. 


\section{APPENDIX. Handout for Conclusion of the Interview}

Thank you for participating in the interview today. Here are some explanations of the copyright implications of the Case Studies.

\section{Case Study 1: A photograph taken by a student for a class project.}

There are no formal requirements to own a copyright other than the requirement that the work be minimally creative and fixed or written down or recorded. Thus, when the student took the picture of the butterfly, the student created a copyrightable work and the student owned the copyright for the work.

When the student submitted the photograph to the instructor along with the written assignment, the student allowed the instructor to "own" the physical copy of the work, but the student retained ownership over the intellectual property or the creativity/copyright of the work.

\section{Case Study 2: A photograph taken by a professional photographer from the internet to be used in a class project.}

Although it is a common myth that everything placed on the internet waives copyright, that is incorrect. The copyright in the photograph taken by a professional photographer is owned by the person who took the photo (or the photographer). However, there are numerous exceptions to copyright for educational purposes including the face-to-face teaching exception, whereby the student could display the work of another in the classroom without violating copyright. Here, the student wishes to make a copy of the work and incorporate it into a poster. If the face-to-face teaching exception does not apply, this use may be a fair use. Fair use is a limitation on the rights of the copyright owner where the user of the work does not need permission to use the work. Fair use must be considered on a case-by-case basis (in other words, not every educational use is a fair use) and it does involve a risk assessment (the copyright owner could still sue you and you would need to assert a defense of fair use).

If you would like more information about copyright in general and fair use, please review the Copyright Reference Guide, located at: https://guides.library.illinois.edu/copyrightreferenceguide

If you have additional questions, please feel free to reach out to us at:

Sara Benson, Copyright Librarian, srbenson@illinois.edu

Kelli Trei, Biosciences Librarian, ktrei2@illinois.edu

Merinda Kaye Hensley, Digital Scholarship Liaison and Instruction Librarian, mhensle1@ illinois.edu

\section{Notes}

1. Ithaka S+R, University of Illinois at Urbana-Champaign Undergraduate Student Survey: Report of Findings (New York, NY: ITHAKA, 2018), available online at https://www.library.illinois.edu/staff/assessment/libsurv/ [accessed 17 November 2020].

2. Nancy Sims, "Kids These Days... May Know More about Copyright than You," in Copyright Conversations: Rights Literacy in a Digital World, ed. Sara R. Benson (Chicago, IL: ACRL, 2019), 1-16.

3. Adeyinka Tella and Frencis Oyeyemi, “Undergraduate Students' Knowledge of Copyright Infringement," Brazilian Journal of Information Studies 11, no. 2 (2017): 40, https://doi.org/10.36311/1981-1640.2017.v11n2.05.p38.

4. Tella and Oyeyemi, “Undergraduate Students' Knowledge of Copyright Infringement," 45. 
5. Tella and Oyeyemi, “Undergraduate Students' Knowledge of Copyright Infringement," 50.

6. Enrique Muriel-Torrado and Juan-Carlos Fernández-Molina, "Creation and Use of Intellectual Works in the Academic Environment: Students' Knowledge About Copyright and Copyleft," Journal of Academic Librarianship 41, no. 4 (2015): 443-46, https://doi.org/10.1016/j.acalib.2015.05.001.

7. Chien Chou, Pei-Shan Chan, and Huan-Chueh Wu, 'Using a Two-Tier Test to Assess Students' Understanding and Alternative Conceptions of Cyber Copyright Laws," British Journal of Educational Technology 38, no. 6 (2007): 1076-77, https://doi.org/10.1111/j.1467-8535.2006.00695.x.

8. Education for Change, Researchers of Tomorrow: The Research Behaviour of Generation Y Doctoral Students (Bristol, UK: Jisc, 2012), last modified February 3, 2015, available online at https://www.jisc.ac.uk/reports/ researchers-of-tomorrow [accessed 18 September 2020].

9. Sims, "Kids These Days," 6.

10. Catherine Fraser Riehle and Merinda Kaye Hensley, "What Do Undergraduate Students Know about Scholarly Communication? A Mixed Methods Study," portal: Libraries and the Academy 17, no. 1 (2017): 165, https:// doi.org/10.1353/pla.2017.0009.

11. Riehle and Hensley, "What Do Undergraduate Students Know about Scholarly Communication?" 165.

12. Lucy Mercer-Mapstone et al., "A Systematic Literature Review of Students as Partners in Higher Education," International Journal for Students as Partners 1, no. 1 (2017): 1-23, https://doi.org/10.15173/ijsap.v1i1.3119.

13. Association of College and Research Libraries (ACRL), Working Group on Intersections of Scholarly Communication and Information Literacy, Intersections of Scholarly Communication and Information Literacy: Creating Strategic Collaborations for a Changing Academic Environment (Chicago, IL: Association of College and Research Libraries, 2013), https://acrl.ala.org/intersections/ [accessed 17 November 2020].

14. ACRL, Working Group on Intersections of Scholarly Communication and Information Literacy, Intersections of Scholarly Communication and Information Literacy, 16.

15. Coaching Copyright, eds. Kevin L. Smith and Erin L. Ellis (Chicago, IL: American Library Association, 2020).

16. Elizabeth Joan Kelly, "Rights Instruction for Undergraduate Students: Needs, Trends, and Resources," College \& Undergraduate Libraries 25, no. 1 (2018): 1-16, https://doi.org/10.1080/10691316.2016.1275910.

17. Gail Clement and Stephanie Brenenson, "Theft of the Mind: An Innovative Approach to Plagiarism and Copyright Education," in Common Ground at the Nexus of Information Literacy and Scholarly Communication, eds. Stephanie Davis-Kahl and Merinda Kaye Hensley (Chicago, IL: ACRL, 2013), 45, https://digitalcommons.iwu. edu/bookshelf/36/ [accessed 17 November 2020].

18. Molly Keener, “Contextualizing Copyright: Fostering Students' Understanding of Their Rights and Responsibilities as Content Creators," Virginia Libraries 61, no. 1 (2015): 37-42, http://doi.org/10.21061/valib.v61i1.1328.

19. Kyra Folk-Farber, "Engaging Undergraduates in Copyright and Fair Use Fundamentals," College \& Undergraduate Libraries 23, no. 4 (2016): 460, https://doi.org/10.1080/10691316.2016.1245020.

20. American Library Association, $A L A^{\prime}$ 's Core Competences of Librarianship (January 27, 2009), available online at www.ala.org/educationcareers/careers/corecomp/corecompetences [accessed 18 September 2020].

21. Special Libraries Association, Competencies for Information Professionals (April 13, 2016), available online at https://web.archive.org/web/20170321172834/http://www.sla.org:80/about-sla/competencies/ [accessed 18 September 2020].

22. Association of College and Research Libraries, Framework for Information Literacy for Higher Education (February 2, 2015), available online at www.ala.org/acrl/sites/ala.org.acrl/files/content/issues/infolit/framework1. pdf [accessed 18 September 2020].

23. LeEtta Schmidt and Michael English, "Copyright Instruction in LIS Programs: Report of a Survey of Standards in the U.S.A.," Journal of Academic Librarianship 41, no. 6 (2015): 741, https://doi.org/10.1016/j.acalib.2015.08.004.

24. Laura Saunders and Allison N. Estell, "Copyright Literacy of Library and Information Science Students in the United States," Journal of Education for Library and Information Science 60, no. 4 (2019): 338, https://doi.org/10.3138/ jelis.2018-0059.

25. Saunders and Estell, "Copyright Literacy of Library and Information Science Students in the United States," 340.

26. Sharon B. Merriam and Elizabeth J. Tisdell, Qualitative Research: A Guide to Design and Implementation, 2nd ed. (Hoboken, NJ: John Wiley \& Sons, 2015): 16-18.

27. Study in the States, Eligible CIP Codes for the STEM OPT Extension (Washington, DC: Department of Homeland Security, 2016), available online at https://studyinthestates.dhs.gov/stem-opt-hub/eligible-cip-codesfor-the-stem-opt-extension [accessed 18 September 2020].

28. Rev, "Rev," available online at www.rev.com [accessed 18 September 2020].

29. Merriam and Tisdell, Qualitative Research, 204, 206. 
30. 17 U.S.C. $\S 106$ (2018).

31. Feist Publications, Inc. v. Rural Telephone Serv. Co., Inc., 499 U.S. 340, 369 (1991).

32. 17 U.S.C. $\S 106$ (2018).

33. Feist Publications, Inc., 499 U.S. at 359-60.

34. Marcus v. Rowley, 695 F.2d 1171, 1176 n.8 (9th Cir. 1983) (noting that attribution is one factor that is considered by courts when determining whether fair use was justified).

35. Marcus v. Rowley, 695 F.2d 1171, 1176 n.8 (9th Cir. 1983); 17 U.S.C. § 107 (2018).

36. See, for example, Jessica Vogele, "Where's the Fair Use? The Takedown of Let's Play and Reaction Videos on YouTube and the Need for Comprehensive DMCA Reform," Touro Law Review 33, no. 2 (2017): Article 13, available online at https://digitalcommons.tourolaw.edu/lawreview/vol33/iss2/13 [accessed 18 November 2020]. 37. Sims, "Kids These Days," 10. 